\title{
Effects of Heavy Metals on Soil Enzymatic Activities in the Ishiagu Mining Area of Ebonyi State-Nigeria.
}

\author{
C.J. Ofoegbu ${ }^{1}$, E.I. Akubugwo ${ }^{1}$, C.C. Dike ${ }^{2 *}$, H.C.C.Maduka ${ }^{2}$,C.E.Ugwu ${ }^{2}$, \\ N.A. Obasi ${ }^{1}$, \\ ${ }^{I}$ Department of Biochemistry, Abia State University, P.M.B. 2000, Uturu, Abia State, Nigeria. \\ ${ }^{2}$ Department of Human Biochemistry, College of Health Sciences, Nnamdi Azikiwe University, P.M.B.5001, \\ Nnewi-Anambra State,Nigeria. Pin Code 23459961
}

\begin{abstract}
Effects of heavy metal pollution on the enzymatic activities of soils were investigated in the Ishiagu mining area of Ebonyi State, Nigeria. Soil dehydrogenase, polyphenol oxidase, hydrogen peroxidase, alkaline and acid phosphatases and urease were measured to evaluate the effects of heavy metals mining operations on soil biochemical characteristics. Results showed that the soil pH ranged from 5.04 to 6.56 while the heavy metals were of the ranges: $\mathrm{Pb}(13,754-29,491 \mathrm{mg} / \mathrm{kg}), \mathrm{Zn}(1,151-2,778 \mathrm{mg} / \mathrm{kg}), \mathrm{Cd}(17.65-27.71 \mathrm{mg} / \mathrm{kg}), \mathrm{Cu}$ $(9.59-39.91 \mathrm{mg} / \mathrm{kg})$ and total heavy metals $(014,932.24-32,336.62 \mathrm{mg} / \mathrm{kg})$. Soil heavy metals concentrations significantly decreased with the increase of distance from the mining pit while soil $\mathrm{pH}$ increased with the increase of the distance from the mining pit. Analysis of the soil enzyme activities indicated a significant positive correlation at $P \leq 0.05$ between soil enzyme activities and soil $p H$. On the contrary, the activities of dehydrogenase, polyphenol oxidase, hydrogen peroxidase, alkaline and acid phosphatases and urease showed significant negative correlation at $P \leq 0.05$ with the heavy metal contents except for Zn against dehydrogenase activity and Cd against hydrogen preoxidase and urase activities that were though negative but statistically not significantly correlated at $P \leq 0.05$. This showed that the activities of the enzymes analysed could be used as sensitive indicators of heavy metals contamination. The results in general indicated that the mining operations at Ishiagu, Ebonyi State affect the soil quality due to heavy metal contamination.
\end{abstract}

Key words: Enzyme activities, heavy metals, Ishiagu, soil, pollution.

\section{Introduction}

Contamination and subsequent pollution of the environment by toxic heavy metals has become an issue of global concern due to their sources, widespread distribution and multiple effects on the ecosystem.

Soil does not only provide a place for plants, animals and microbial life, but also a natural reservoir for metals. Its heavy metal concentration is associated with biogeochemical cycle, parent material, mineralogy, soil age, organic matter, particle size distribution, soil $\mathrm{pH}$, redox concentration, oxidation state and microbial activities $[1] ;[2] .,[3] ;] ;[4]$.

Aside these natural processes, anthropogenic activities, such as agricultural practices, industrial activities, military activities and waste disposal methods tend to increase the concentrations of heavy metals and other trace elements in the soil [5];[6]. These anthropogenic sources of metal loading interact with the preexisting natural sources of metal that originated from metal-rich parent material [7]. Such conditions resulting to excessive accumulation of heavy metals in the soil are frequently found in areas with metal mining operations like that of Ishiagu.

Excessive amount of heavy metals affects soil biological properties and may change its basic physicochemical properties. [8] showed that microbial respiration was reduced in soil contaminated with heavy metals. Also, [9] reported that cadmium and zinc led to a reduction in soil respiration.

Moderation of many other biological processes of the soil such as the count and species diversity of macro-and microorganisms and changes in enzymatic activities resulting from contamination with heavy metals has been well documented [10]; [11]; [12]; [13] for various anthrogenic sources of heavy metals but not in Ishiagu mining area.

The effects of heavy metals mining operations on soil enzymatic activities in Ishiagu have not been documented. To understand if soil functions or biochemical characteristics are affected by long term metals mining operations, soil enzymatic activities in Ishiagu heavy metals mining area were evaluated in this study.

\subsection{Sampling sites}

\section{Materials and method}

The sampling site is located in Ishiagu in Ivo Local Government Area of Ebonyi State, Nigeria. The area lies between latitude $5^{0} 51^{\prime}$ and $5^{0} 59^{\prime} \mathrm{N}$ and Longitude $7^{0} 24^{\prime}$ and $7^{0} 40^{\prime} \mathrm{E}$ and is typically of tropical 
climatic conditions with guinea savanna features, covering an area of over 8000 square Kilometers. The industrial activity in the area is predominated by metal mining, which has been going on for over twenty-five (25) years with its attendant environmental pollution. Quarrying activities (rock blasting) is also enormous in the area. However the local dwellers are mainly farmers, producing mainly staple crops.

\subsubsection{Sample collection and analysis}

This study was conducted between the months of July and August 2007. Four sampling points designated as 0 meter, 5 meters, 10 meters and 30 meters were mapped out from a randomly selected excavated site. A farmland, about 500 meters away from the excavated site was used as the control. Three (3) replicate soil samples were randomly collected from each of the sampling points at a depth of $15 \mathrm{~cm}$ and pooled together to obtain a homogenous unity sample. The soil samples were transported in plastic bags to the department of biochemistry laboratories of Abia State University, Uturu, where the soil enzymatic activities were analysed. Heavy metal analysis was done at a commercial analytical laboratory in Port Harcourt, Rivers state, Nigeria. The soil $\mathrm{pH}$ was determined ex situ from 1:2.5 fresh soil/water ratios, using the glass electrode $\mathrm{pH}$ meter as described by [14].

\subsubsection{Analysis of heavy metals}

The heavy metals contents of the soil samples were determined according to the procedure of [15]. $0.5 \mathrm{~g}$ of air-dried soil sample was weighed into a digestion flask to which was added $10 \mathrm{ml}$ of aqua riga $(3 \mathrm{HCl}$ : $1 \mathrm{HNO}_{3}$ ). The mixture was shaken and heated on a hot plate until near dryness. The digest was allowed to cool and $20 \mathrm{ml}$ of deionized water was added to it and stirred. This was filtered through a whatman No. 42 filter paper into a $50 \mathrm{~mL}$ vol. flask with rinsing using deionized water and made up to the mark with deionized water. A blank digestion was also carried out using the same procedure. The test sample filtrates were run in an atomic absorption spectrophotometer against the blank using the appropriate cathode lamp and wavelength. Lead was determined at $285 \mathrm{~nm}$, Zinc at $213 \mathrm{~nm}$, Cadmium at $227 \mathrm{~nm}$ and Copper at $324 \mathrm{~nm}$.

\subsubsection{Analysis of soil enzymatic activities}

Soil dehydrogenase activity was determined by the method of [16] as modified by [17] using $0.25 \%$ triphenyl tetrazolium chloride (TTC) solution per 5g of dry soil sample. TTC is converted to triphenyl formazan (TPF) that is detected using a spectrophotometer at $485 \mathrm{~mm}$ after incubation for 6 hours at $37^{\circ} \mathrm{C}$. Polyphenol oxidase activity was determined based on the formation of purpurogallin from pyrogallic acid amended soil sample after 3 hours incubation at $30^{\circ} \mathrm{C}$ which absorbance was measured at $450 \mathrm{~mm}$ as outlined by [17] in a method modified from [18].

Acid phosphatase and alkaline phosphatase activities were determined according to the procedure described by [19] and [18]. $2 \mathrm{~g}$ of dry soil sample were incubated with $5 \mathrm{ml}$ of $5 \mathrm{mM}$ p-nitro phenylphosphate substrate at $20^{\circ} \mathrm{C}$ for $1 \mathrm{hr}$. The soil sample for acid phosphatase activity was brought to $\mathrm{pH}$ of 4.9 while that of alkaline phosphatase activity was brought to $\mathrm{pH}$ of 10.0 with the substrate buffer. $0.1 \mathrm{ml}$ each of $0.5 \mathrm{M} \mathrm{CaCl}_{2}$ and $0.5 \mathrm{M} \mathrm{NaOH}$ were added to $2 \mathrm{ml}$ of the supernatant, which was transferred to a clean sterile tube after centrifugation at $3000 \mathrm{xg}$ for $3 \mathrm{~min}$ to halt the enzymatic activity and facilitate colour development. Prior to spectrophotometric analysis at $410 \mathrm{~nm}$, each sample of the supernatant was diluted with $8 \mathrm{~mL}$ of distilled/deionized water.

Soil urease activity was determined by the method of [20 ]and [21] based on the $\mathrm{NH}_{3}-\mathrm{N}$ formation in the urea-amended soil sample after 5 hours incubation at $37^{\circ} \mathrm{C} .5 \mathrm{~g}$ of dry soil sample were amended with $1 \mathrm{~mL}$ of $60 \mathrm{mM}$ urea solution incubated with $5 \mathrm{ml}$ of distilled water at $37^{\circ} \mathrm{C}$ and intermittently shake for 5 hours. $2 \mathrm{~mL}$ of phenylmercury acetate solution in $2 \mathrm{M} \mathrm{KCl}$ was added to stop the reaction. The mixture was centrifuged and the concentration of the $\mathrm{NH}_{3}-\mathrm{N}$ was determined spectrophotometrically and the soil urease activity was expressed as $\mathrm{mg} \mathrm{NH} \mathrm{NH}_{3} \mathrm{~N}$ g-1 dry soil $5 \mathrm{~h}^{-1}$

Hydrogen peroxidase activity was determined by the $\mathrm{KMn}_{4}$ titration method according to [22].

\subsubsection{Data analysis}

Statistical analysis was done using Pearson's simple correlation coefficient analysis. The population correlation coefficients were compared for significance using the hypothesis test for population correlation coefficient $(\mathrm{P} \leq 0.05)[23]$.

\section{Result}

The $\mathrm{pH}$ and the heavy metal content of the soil from the Ishiagu mining area are shown in table 1 . The heavy metal content decreased with distance away from the pit. The $\mathrm{pH}$ of the soil ranged from 5.04 to 6.56 decreasing with the increase of the distance from the pit. $\mathrm{Pb}$ was the most abundant of the four heavy metals assessed with values ranging from $568 \mathrm{mg} / \mathrm{kg}$ to $29,491 \mathrm{mg} / \mathrm{kg}$. Compared to the control, the total heavy metal 
content was 29.2 times greater at the pit region and 13.5 times greater at distance 30 meters away from the pit. The $\mathrm{pH}$ of the soil was negatively correlated with the heavy metal content (Table 3 ). There were significant positive correlation between $\mathrm{Pb}, \mathrm{Zn}, \mathrm{Cd}, \mathrm{Cu}$ and the total heavy metals at $\mathrm{P} \leq 0.05$. Soil heavy metals concentrations significantly decreased with the increase of the distance from the pit.

Table 2 shows the enzyme activities of the soil from the Ishiagu mining area. The soil enzyme activities decreased with the decrease of distance from the pit. In comparison to the control, there was a reduction in dehydrogenase activity by $36.34 \%$, polyphenol oxidase by $20.42 \%$, hydrogen peroxidase by $10.45 \%$, alkaline phosphatase by $17.02 \%$, acid phosphatase by $21.15 \%$ and urease by $9.32 \%$ at 30 meters away from the pit. There were significant positve correlation between the activities of soil enzymes and the soil $\mathrm{pH}$. On the contrary, there were significant negative correlation between the activities of soil enzymes analyzed and the heavy metal contents of the soil. Data analyses showed a significant negative linear relationship between the heavy metal contents and the activities of the soil enzymes at $\mathrm{P} \leq 0.05$ except for $\mathrm{Zn}$ against dehydrogenase activity and $\mathrm{Cd}$ against hydrogen peroxidase and urease activities where the correlation were though negative but not statistically significant.

\section{Discussion}

Soil enzymes have been proposed as useful indicators of soil quality. They play an important role in chemical changes involving soil nutrients. Dehydrogenase plays an essential role in the initial stages of the oxidation of soil organic matter by transferring hydrogen and electrons from substrates to acceptors [3]. Hydrogen peroxidase is associated with aerobic microbial activities, and decomposes hydrogen peroxide into molecular oxygen and water, thus alleviating its toxicity to organisms. Polyphenol oxidase is associated with carbon cycle and is important to the formation of humic substances, whereas phosphatases and urease are involved in the biochemical cycles of phosphorus and nitrogen respectively [10]; [17]; [24].

The finding of this research conducted showed that at the current pollution level, the heavy metals in the soil of Ishiagu mining area affects the soil quality as they exhibit inhibitory effect on the soil enzyme activities. [10] and [11] observed similar results in heavy metal polluted soils. However, [7] reported that heavy metal input to agricultural soil does not always inhibit the soil enzyme activities. This could however be attributed to the levels of the heavy metal input or contamination in line with the reports of [25] and [26] who observed that enzyme could be stimulated when the soil heavy metals only slightly exceed natural values but can be inhibited under the influence of excessive heavy metal concentrations. Thus, the mining operations at Ishiagu from the results could be said to have polluted the soils with excessive heavy metals.

There were strong significant negative correlation coefficients between the soil heavy metal contents and the activities of soil enzymes analyzed, except for $\mathrm{Zn}$ against dehydrogenase activity and $\mathrm{Cd}$ against hydrogen peroxidase and urease activities, which were statistically non-significant $(\mathrm{P} \leq 0.05)$. This shows that the levels of heavy metals present in the soil were strongly antagonist to the activities of the soil dehydrogenase, polyphenol oxidase, hydrogen peroxidase, acid and alkaline phosphatases and urease. The results also showed a negative linear relationship between the heavy metals and the activities of soil enzymes implicating that the higher the concentrations of heavy metals, the lower the activities of soil enzymes.

Contrary to this negative linear relationship obtained, [17] reported an increase in the activities of soil dehydrogenase, hydrogen peroxidase and polyphenol oxidase with increasing concentrations of the pollutant. The differences may be attributed to the differences in the pollutants since [17] worked on the effect of petroleum-containing wastewater that is a carbon source, after all. Petroleum aliphatic and polycyclic hydrocarbon can act as sources of carbon and energy for the growth of soil microorganisms [27], hence the increase in the soil enzyme activities.

The soil $\mathrm{pH}$ observed in this study was generally acidic and showed significant negative correlation (P $\leq 0.05)$ with the heavy metal contents and significant positively correlation $(\mathrm{P} \leq 0.05)$ with the soil enzyme activities except for $\mathrm{pH}$ against $\mathrm{Cd}$ where the correlation were negative but statistically not significant.

It is possible that the low soil $\mathrm{pH}$ may have resulted from the eventual transformation of soil sulphur input from the atmospheric sulphur and metal sulphide ores into $\mathrm{H}_{2} \mathrm{SO}_{4}$, which can acidify soil and water. [28] opined that this might be one of the mechanisms of lowering $\mathrm{pH}$ by heavy metals. It is generally expected that low soil $\mathrm{pH}$ elevates the solubility and speciation of heavy metals by releasing from the soil particles heavy metals to the solution, resulting in an enhancement of the toxicity of heavy metals on soil bacteria and plants [29]; [30].

Thus, the reduction in the enzyme activities as observed from this work could be ascribed to the indirect effect of the heavy metals on the number of soil microorganisms and its direct effect on the soil enzymes. [31] and [32] have reported that metal ion may inhibit enzyme reactions by complexing the substrate, reacting with the protein active groups of the enzyme or with the enzyme substrate complex.

The soil dehydrogenase activities was the least tolerant to the heavy metal pollution with $86.46 \%$ activity reduction at 0 meter and $36.34 \%$ reduction at 30 meters away from the pit relative to the control soil. 
This shows that the activities of soil enzymes especially soil dehydrogenase activities are sensitive indicators of heavy metals. The correlation coefficients (table 3 ) between the different heavy metals and the different enzyme activities showed that there is a strong linear relationship between the various individual heavy metals analyzed and the different soil enzyme activities. However, the strength of the relationships did not follow a definite order among the different enzyme activities. This shows that each heavy metal affects a particular enzyme differently and that the actual reduction in activity of a particular enzyme observed from this research could be the joint effect of the total heavy metal content of the soil. [33] reported that heavy metals reduced the activity of soil dehydrogenase by $10-90 \%$ depending on the rate and type of metal involved. The effect of the various individual heavy metals and their combined effect on the different soil enzymes therefore deserve a close study. Also, the results clearly showed that the current pollution level in Ishiagu mining area is excessive and therefore appropriate remediation measures is recommended to avert the multiple effects of heavy metals poisoning in the ecosystem.

\section{Conclusion}

Investigation on the effects of heavy metals pollution on the soil enzymatic activities in the Ishiagu mining area showed that the heavy metal contents of the soil in the area were exceedingly higher than normal and as such has reached pollution levels. This is indicated by their strong antagonistic effect on the soil enzymatic activities. Soil dehydrogenase activity was the most affected by the heavy metal pollution. Thus the activities of the soil enzyme especially those of the soil dehydrogenase could be used as sensitive biological indicators of heavy metals pollution. The $\mathrm{pH}$ of the soil in Ishiagu mining area was found to have played an important role in enhancing the toxicity of the heavy metals. In general, the heavy metals mining operations in Ishiagu area of Ebonyi State, Nigeria affects the soil quality as the soils are contaminated with heavy metals.

\section{Acknowledgement}

We wish to express our gratitude to Dr. V.O. Nwaugo of Abia State University, Uturu, Abia State, Nigeria and Prof. B.A. Uzoukwu of University of Port Harcourt, Rivers State, Nigeria for their technical assistance in this work.

\section{References}

[1] Ebong, G.A., Etuk, H.S., and Johnson, A.S. (2007). Heavy metal accumulation by Talinum Triangulare grown on waste dumpsite in Uyo metropolis, Akwa-Ibom State, Nigeria. Journal of Applied Sciences 7(10): 1404-1409.

[2] Ololade, I.A., Ashoghon, A.O., and Adeyemi, O. (2007). Plants level of Chromium and Nickel at a refuse site. Any positive impact? J. Appl. Sci. 7(13):1768-1773.

[3] Lee, I., Kim, O.K., Chang, Y., Bae, B., Kim, H.H., and Baek, K.H. (2002). Heavy metal concentrations and enzymatic activities in soil from contaminated Korean shooting range. J. Biosci. Bioeng., 94 (5): 406-411.

[4] Ma L.Q., Tam. F., and Harris, W.G. (1997). Concentration and Distribution of eleven metals inFlorida soil. J. Environ. Qual., 26:769-775

[5] Dulka, S., Piotrowska, M., Chlopecka, A., and Witek, T. (1995). Trace element contamination of soils and crop plants by mining smelting industry in southwest Poland. J. Geochem. Explor. 52:232-250.

[6] Dulka, S. (1992). Factor analysis of total element concentrations in Surface soils of Poland. Sci.Total Environ, 121:39-52.

[7] Stuczynski, T.I., McCarty, G.W., and Siebielec, G. (2003). Response of Soil Microbiological activities to cadmium, lead and zinc salt amendments. J. Environ. Qual., 32:1346-1355.

[8] Doelmann, P., and Haanstra, L. (1984). Short-term and long-term effects of $\mathrm{Cd}, \mathrm{Cr}, \mathrm{Cu}, \mathrm{Ni}, \mathrm{Pb}$ and $\mathrm{Zn}$ on microbial respiration in relation to abiotic soil factors. Plant and soil, 79: 317- 321.

[9] Chaney, W.R., Kelly, J.M., and Strickland, R.C. (1978). Influence of Cd And Zn on carbon dioxide evolution from litter and soil from a black forest. J. Environ. Qual., 7: 115-119.

[10] Koper, J., Dabkowska-Naskret, H., and Piotrowska, A. (2005). Influence of heavy metals on enzymatic activity in lessive soils of Kujawy and Pomoroze region (Poland). Geophysical Research Abstracts, 7:10565-10569.

[11] Wyszkowska, J., and Kucharski, J. (2003). Effect of soil contamination with copper on its enzymatic activity and physicochemical properties, Electromic Journal of Aricultural Unieresities, 6(2): 389-395.

[12] Wyszkowska, J., and Wyszkowski, M. (2003). Effect of cadmium andmagnesium on enzymatic activity in soil . Pol. J. Environ. Stud. 12 (4): 473- 479.

[13] McGrath, S.P, Chaudri, A.M., and Giller, K.E. (1995). Long-term effects of metals in sewage sludge on soils, microorganisms and plants. J. Ind. Microbiol., 14: 94-104.

[14] Bates, R.G. (1954). Electrometric pH determinations. John Wiley and Sons Inc., New York. Pp 87-92.

[15] AOAC (2005). Official methods of analysis of Association of Official Analytical Chemists, (18 ${ }^{\text {th }}$ edn.). Washington, D.C. Pp A1106-A1113.

[16] Cassida, L.E., Klein, D.A., and Santoro, T. (1964). Soil dehydrogenase Activity. Soil Sci., 98: 371-376.

[17] Li, H., Zhang, Y., Zhang, C.G., and Chen, G.X. (2005). Effect of Petroleum-containing wastewater irrigation on bacteria diversities and enzymatic activities in a paddy soil irrigation area. J. Environ. Qual., 34:1073-1080.

[18] Tabatabai, M. A., and Bremner, J. M. (1969). Use of P- nitro phenyl Phosphate for assay of soil phosphatase activity. Soil Biol. Biochem., 1:301-307.

[19] Tabatabai, M.A. (1982). Soil enzymes. In: Methods of soil analysis, part 2. Agronomy monograph Vol 9. Page, A. L. (ed), American society of Agronomy, Madison, Pp: 903-904.

[20] Nannipieri, P. Ceccanti, C., Cervell, S., and Matarese, E. (1980). Extraction of phosphatase, urease, protease, organic carbon and nitrogen from soil. Soil Sci Soc. Am. J., 44:10111016. 
[21] Kandeler, E., and Gerber, H. (1988). Short-term assay of soil urease activity using colorimetric determination of ammonia. Biol. Fertil. Soils, 6:68-72.

[22] Alef, K., and Nannipieri, P. (1995). Methods in applied soil Microbiology and biochemistry. Academic press, New York, Pp 214 218.

[23] Nwachukwu, V.O. (2006). Principles of statistical inference $\left(2^{\text {nd }}\right.$ edn). Zelon Enterprices, Port Harcourt, Pp: 175-202.

[24] Matocha, C.J., Haszler, G.R., and Grove, J.H. (2004). Nitrogen Fertilization Suppresses soil phenol oxidase enzyme activity in notillage systems. Soil Science Technical Articles 169(10): 708-714.

[25] Sandrin, T.R., and Maier, R.M. (2003). Impact of metals on the Biodegradation of organic pollutants.Environ.HealthPerspectives, 111(8): 1093-1101.

[26] Moreno, J.L., Garcia, C., Landi, L., Falchini, L., Pietramellara, G., and Nannipieri, P. (2001). The ecological dose value (ED $\left.D_{50}\right)$ for assessing Cd toxicity on ATP content and dehydrogenase and urease activities of soil. Soil Biol. Biochem, 33(4-5): 483-489.

[27] Galli, E. (1998). Evolution of new degradative pathway in Microorganisms of environmental interest. In: Biotechnology for soil remediation: Scientific bases and practical applications. Serra, P. (ed) CIPA, Milan, Pp: 67-80.

[28] Mitchell, M.J., Driscoll, C.T., Fuller, R.D, David, M.B, and Likens, G.E.(1989). Effect of whole tree harvesting on the sulphur dynamics of a forest soil. Soil Sci. Am. J. $53: 933-940$.

[29] Oliveira, A., and Pampulha, M.E. (2006). Effects of long-term heavy metal contamination on soil microbial characteristics. $J$. Biosci. Bioeng., 102(3):157-161.

[30] Saeki, K., Kunito, T., Oyaizu, H., and Matsumoto, S. (2002). Relationships between bacterial tolerance levels and forms of copper and zinc in soils. J. Environ Qual., 31:1570-1575.

[31] Nies, D.H. (1999). Microbial heavy metal resistance. Molecular biology and utilization biotechnological processes. Appl. Microbiol. Biotechnol., 51 (6):730-750.

[32] Deng, S.P., and Tabatabai, M.A. (1995). Cellulase activity of soils: Effect of trace elements. Soil Biol. Biochem., 27 (7) :977-979.

[33] Welp, G. (1999). Inhibiting effects of the total and water soluble Concentrations of nine different metals on dehydrogenase activity of a loess soil. Biol. Fertil. Soils. 30(1-2):132-139.

Table 1: $\mathrm{pH}$ and concentration of heavy metals in soil from the Ishiagu mining area.

\begin{tabular}{|l|l|l|l|l|l|l|}
\hline $\begin{array}{l}\text { Soil sample distance from } \\
\text { the pit (meters) }\end{array}$ & $\mathrm{PH}$ & $\mathrm{Pb}(\mathrm{mg} / \mathrm{kg})$ & $\mathrm{Zn}(\mathrm{mg} / \mathrm{kg})$ & $\mathrm{Cd}(\mathrm{mg} / \mathrm{kg})$ & $\mathrm{Cu}(\mathrm{mg} / \mathrm{kg})$ & Total heavy metals $(\mathrm{mg} / \mathrm{kg})$ \\
\hline 0 & 5.04 & 29,491 & 2,778 & 27.71 & 39.91 & $32,336.62$ \\
\hline 5 & 5.74 & 20,106 & 1,725 & 20.37 & 31.85 & $21,883.22$ \\
\hline 10 & 6.37 & 17,687 & 1,157 & 18.94 & 17.31 & $18,880.25$ \\
\hline 30 & 6.56 & 13,754 & 1,151 & 17.65 & 9.59 & $14,932.24$ \\
\hline Control & 6.86 & 568 & 534 & 2.86 & 3.65 & $1,108.51$ \\
\hline
\end{tabular}

NB: $\quad$ Figures represent mean $(n=3)$

Table 2: Soil enzyme activities in soil from the Ishiagu mining area.

\begin{tabular}{|c|c|c|c|c|c|c|}
\hline $\begin{array}{l}\text { Soil sample } \\
\text { distance from } \\
\text { the pit (meters) }\end{array}$ & $\begin{array}{l}\text { Dehydrogen } \\
\text { ase } \\
\left(\mathrm{mg} \mathrm{g}^{-1} 6 \mathrm{~h}^{-1}\right)\end{array}$ & $\begin{array}{l}\text { Polyphenol } \\
\text { oxidase } \\
\left(\mathrm{mg} \mathrm{g}^{-1} 3 \mathrm{~h}^{-1}\right)\end{array}$ & $\begin{array}{l}\text { Hydrogen } \\
\text { peroxidase } \\
\left(\mathrm{mlg}^{-1}\right)\end{array}$ & $\begin{array}{l}\text { Alkaline } \\
\text { Phosphatase } \\
\left(\mathrm{mg} \mathrm{g}^{-1} \mathrm{~h}^{-1}\right)\end{array}$ & $\begin{array}{l}\text { Acid } \\
\text { Phosphatas } \\
\text { e } \\
\left(\mathrm{mg} \mathrm{g}^{-1} \mathrm{~h}^{-1}\right)\end{array}$ & $\begin{array}{l}\text { Urease } \\
\left(\mathrm{mg} \mathrm{g}^{-1} 6 \mathrm{~h}^{-}\right. \\
\left.{ }^{1}\right)\end{array}$ \\
\hline 0 & 0.60 & 0.82 & 0.75 & 0.75 & 0.42 & 0.54 \\
\hline 5 & 1.21 & 1.87 & 1.47 & 1.32 & 0.91 & 1.10 \\
\hline 10 & 1.63 & 1.92 & 2.01 & 1.47 & 1.21 & 2.61 \\
\hline 30 & 2.82 & 2.26 & 2.57 & 1.56 & 1.64 & 3.31 \\
\hline Control & 4.43 & 2.84 & 2.87 & 1.88 & 2.08 & 3.65 \\
\hline
\end{tabular}

NB: $\quad$ Figures represent mean $(n=3)$

Table 3: correlation coefficients between $\mathrm{pH}$, heavy metal content and soil enzyme activities in soil from

NB: $\quad *$ Implies non significantly different at $\mathrm{P} \leq 0.05$ the Ishiagu mining area.

\begin{tabular}{|c|c|c|c|c|c|c|c|c|c|c|c|c|}
\hline $\begin{array}{l}\text { Variable } \\
\text { s }\end{array}$ & $\mathrm{pH}$ & $\mathrm{Pb}$ & $\mathrm{Zn}$ & $\mathrm{Cd}$ & $\mathrm{Cu}$ & THM & Deh & PPO & HPx & ALP & ACP & $\begin{array}{l}\text { Ureas } \\
\mathrm{e}\end{array}$ \\
\hline pH & 1.000 & & & & & & & & & & & \\
\hline $\mathrm{Pb}$ & -0.917 & 1.000 & & & & & & & & & & \\
\hline $\mathrm{Zn}$ & -0.986 & 0.936 & 1.000 & & & & & & & & & \\
\hline $\mathrm{Cd}$ & - $0.854 *$ & 0.984 & 0.888 & 1.000 & & & & & & & & \\
\hline $\mathrm{Cu}$ & -0.983 & 0.920 & 0.948 & $0.854^{*}$ & 1.000 & & & & & & & \\
\hline THM & -0.926 & 0.999 & 0.945 & 0.981 & 0.926 & 1.000 & & & & & & \\
\hline Deh & 0.880 & $\begin{array}{l}- \\
0.974\end{array}$ & - $0.869 *$ & -0.955 & $\begin{array}{l}- \\
0.923\end{array}$ & $\begin{array}{l} \\
0.971\end{array}$ & $\begin{array}{l}1.00 \\
0\end{array}$ & & & & & \\
\hline$\overline{\mathrm{PPO}}$ & 0.951 & $\begin{array}{l}- \\
0.967\end{array}$ & -0.973 & -0.923 & $\begin{array}{l}- \\
0.921\end{array}$ & $\begin{array}{l}-972 \\
0.972\end{array}$ & $\begin{array}{l}0.91 \\
2 \\
\end{array}$ & $\begin{array}{l}1.00 \\
0 \\
\end{array}$ & & & & \\
\hline HPx & 0.987 & $\begin{array}{l} \\
0.936\end{array}$ & -0.963 & $\overline{0.871 *}$ & $\begin{array}{l}- \\
0.991\end{array}$ & $\overline{0}-942$ & $\begin{array}{l}0.92 \\
7\end{array}$ & $\begin{array}{l}0.95 \\
7\end{array}$ & $\begin{array}{l}1.00 \\
0\end{array}$ & & & \\
\hline
\end{tabular}


Effects of Heavy Metals on Soil Enzymatic Activities in the Ishiagu Mining Area of Ebonyi State

\begin{tabular}{|l|l|l|l|l|l|l|l|l|l|l|l|l|}
\hline ALP & 0.973 & - & -0.993 & -0.914 & - & - & 0.89 & 0.99 & 0.96 & 1.00 & & \\
& & 0.956 & & & 0.937 & 0.963 & 2 & 3 & 3 & 0 & & \\
\hline ACP & 0.965 & - & -0.951 & -0.928 & - & - & 0.97 & 0.96 & 0.98 & 0.96 & 1.000 & \\
& & 0.974 & & & 0.979 & 0.977 & 1 & 5 & 9 & 1 & & \\
\hline urease & 0.976 & - & -0.930 & - & - & - & 0.89 & 0.89 & 0.98 & 0.91 & 0.962 & 1.000 \\
& & 0.889 & & $0.819 *$ & 0.997 & 0.896 & 9 & 1 & 2 & 3 & & \\
\hline
\end{tabular}

Deh $=$ Dehydrogenase

ALP $=$ Alkaline Phosphatase

ACP $=$ Acid Phosphatase

THM=Total Heavy Metals

$\mathrm{PPO}=$ Polyphenol Oxidase

$\mathrm{HPx}=$ Hydrogen Peroxidase 